Article

\title{
Phylogenetic Relationships among Whiteflies in the Bemisia tabaci (Gennadius) Species Complex from Major Cassava Growing Areas in Kenya
}

\author{
Duke M. Manani ${ }^{1, *}$, Elijah M. Ateka ${ }^{2}$, Steven R. G. Nyanjom ${ }^{1}$ and Laura M. Boykin ${ }^{3,4, *}$ \\ 1 Department of Biochemistry, Jomo Kenyatta University of Agriculture and Technology, Nairobi P.O. Box \\ 62000-00200, Kenya; snyanjom@gmail.com \\ 2 Department of Horticulture, Jomo Kenyatta University of Agriculture and Technology, Nairobi P.O. Box \\ 62000-00200, Kenya; eateka@agr.jkuat.ac.ke \\ 3 Australian Research Council Centre of Excellence in Plant Energy Biology, The University of \\ Western Australia, Crawley, WA 6009, Australia \\ 4 School of Molecular Sciences, The University of Western Australia, Crawley, WA 6009, Australia \\ * Correspondence: mogareduke@gmail.com (D.M.M.); laura.boykin@uwa.edu.au (L.M.B.); \\ Tel.: +254-721-931-663 (D.M.M.)
}

Academic Editor: Mary L. Cornelius

Received: 26 October 2016; Accepted: 15 February 2017; Published: 23 February 2017

\begin{abstract}
Whiteflies, Bemisia tabaci (Gennadius) are major insect pests that affect many crops such as cassava, tomato, beans, cotton, cucurbits, potato, sweet potato, and ornamental crops. Bemisia tabaci transmits viral diseases, namely cassava mosaic and cassava brown streak diseases, which are the main constraints to cassava production, causing huge losses to many small-scale farmers. The aim of this work was to determine the phylogenetic relationships among Bemisia tabaci species in major cassava growing areas of Kenya. Surveys were carried out between 2013 and 2015 in major cassava growing areas (Western, Nyanza, Eastern, and Coast regions), for cassava mosaic disease (CMD) and cassava brown streak disease (CBSD). Mitochondrial cytochrome oxidase I (mtCOI-DNA) was used to determine the genetic diversity of B. tabaci. Phylogenetic trees were constructed using Bayesian methods to understand the genetic diversity across the study regions. Phylogenetic analysis revealed two B. tabaci species present in Kenya, sub-Saharan Africa 1 and 2 comprising five distinct clades (A-E) with percent sequence similarity ranging from $97.7 \%$ to $99.5 \%$. Clades B, C, D, and $\mathrm{E}$ are predominantly distributed in the Western and Nyanza regions of Kenya whereas clade B is dominantly found along the coast, the eastern region, and parts of Nyanza. Our B. tabaci clade A groups with sub-Saharan Africa 2-(SSA2) recorded a percent sequence similarity of $99.5 \%$. In this study, we also report the identification of SSA2 after a 15 year absence in Kenya. The SSA2 species associated with CMD has been found in the Western region of Kenya bordering Uganda. More information is needed to determine if these species are differentially involved in the epidemiology of the cassava viruses.
\end{abstract}

Keywords: Bemisia tabaci; genetic diversity; mtCOI; cassava; Kenya; cassava brown streak disease (CBSD); cassava mosaic disease (CMD)

\section{Introduction}

Cassava (Manihot esculenta Crantz, Euphorbiaceae) is an important source of food to more than one fifth of the world's population spread over Africa, Asia, and South America [1]. From the time of its introduction, the crop has spread and gained prominence as a major food and staple crop for many communities in sub-Saharan Africa [2]. On a global basis, cassava is ranked third most important source of carbohydrates in Africa, and it is the second most important food crop after maize in western 
and coastal regions of Kenya [3]. The cassava crop has a wide range of uses; it is a food security-crop which is estimated to be consumed by approximately 500 million people in Africa [4,5]. Cassava is also a cash crop, livestock feed, and a raw material for industrial uses such as pharmaceutical, starch, and alcohol production [6,7].

Cassava roots are a rich source of carbohydrate while leaves are high in proteins, minerals, and vitamins. The roots of cassava save many lives during famine conditions, especially in various parts of Kenya that experience drought, thereby playing a major role in food security and contributing to poverty reduction [2]. Despite this, the crop is affected by two viral diseases namely cassava mosaic disease (CMD) and cassava brown streak virus disease (CBSD). CMD has been a major biotic constraint to cassava production in Africa [8]. In Kenya, the disease is predominantly caused by Geminiviruses, namely African cassava mosaic virus (ACMV) and East African cassava mosaic virus (EACMV) [9]. Symptoms of CMD include leaf chlorotic mottle, distortion of leaves, stem twisting, and crinkling and stunting of cassava plant parts [4,8]. The pandemic affected cassava growing areas in East and Central African countries and has caused severe losses in cassava yields which have been estimated to be approximately 50\% [7,10-13]. CBSD, on the other hand, is caused by Cassava brown streak virus (CBSV) and Uganda cassava brown streak virus (UCBSV) [11,14]. Recent studies have revealed there are several species of CBSD [14], and CBSD has an accelerated rate of evolution [15]. The disease is characterized by severe chlorosis and necrosis on infected leaves, giving them a yellowish, mottled appearance. Chlorosis may be associated with the veins, spanning from the mid vein, secondary and tertiary veins, or rather in blotches unconnected to veins [16]. Brown streaks may appear on the stems of the cassava plant, but in some varieties, a dry brown-black necrotic rot of the cassava root exists, which may progress from a small lesion to the whole root. Finally, the roots may become constricted due to the tuber rot with overall plant stunting, thereby reducing production [17]. The viruses causing CMD and CBSD are transmitted by the whiteflies (Bemisia tabaci) and through infected cuttings. Heavy infestation of B. tabaci on cassava leads to the presence of honey dew and sooty mould that affects the photosynthetic structures reducing cassava production [4,18].

\subsection{Whiteflies as Insect Vectors}

There are over 1500 whitefly species known worldwide in approximately 126 genera [19]. Bemisia tabaci is a species complex that is globally distributed [19] and important because a number of the species that make up the complex are known to damage commercially important plant species either through direct feeding or through the transmission of more than 150 plant viruses primarily belonging to the genus Begomovirus (family: Geminiviridae) [20-22]. It is, therefore, important to control whiteflies with the aim of reducing virus transmission and agronomic losses. The male adult whitefly is about $0.8 \mathrm{~mm}$ while the female is approximately $1 \mathrm{~mm}$ in length. Both sexes have wings that are generally opaque and covered with a whitish powder or wax [19]. The whiteflies undergo incomplete metamorphosis. The females lay 50 to 400 eggs underneath the leaves. The whitish eggs range from $0.10 \mathrm{~mm}$ to $0.25 \mathrm{~mm}$ and change to a brown colour towards the time of hatching within five to seven days. Female whiteflies are diploid and emerge from fertilized eggs whereas male whiteflies are haploid and emerge from unfertilized egg [19]. After the egg stage, the whitefly hatchling develops through four instar stages. In the first instar, commonly called the crawler, the nymph is $0.3 \mathrm{~mm}$ in size and grows to be $0.6 \mathrm{~mm}$ until the fourth instar stage. During the first instar stage the body is greenish in colour and flat in body structure. The mobile whitefly nymph walks on plants to find a suitable area on the leaf with adequate nutrients and moults into four other instar or nymphal stages over the span of 40-50 days until it reaches adulthood. During moulting, the whitefly nymphs shed their silver skins, which are left on the leaves. At the feeding sites, the nymphs use parts of their mouth to stab into the plant and consume the plant's cell sap. The next stage is the pupal stage when the eyes become a deep red colour; the body colour becomes yellow, while the body structure thickens. After development is completed, adult whiteflies have light yellow bodies and white wings (Figure 1, [23]). 


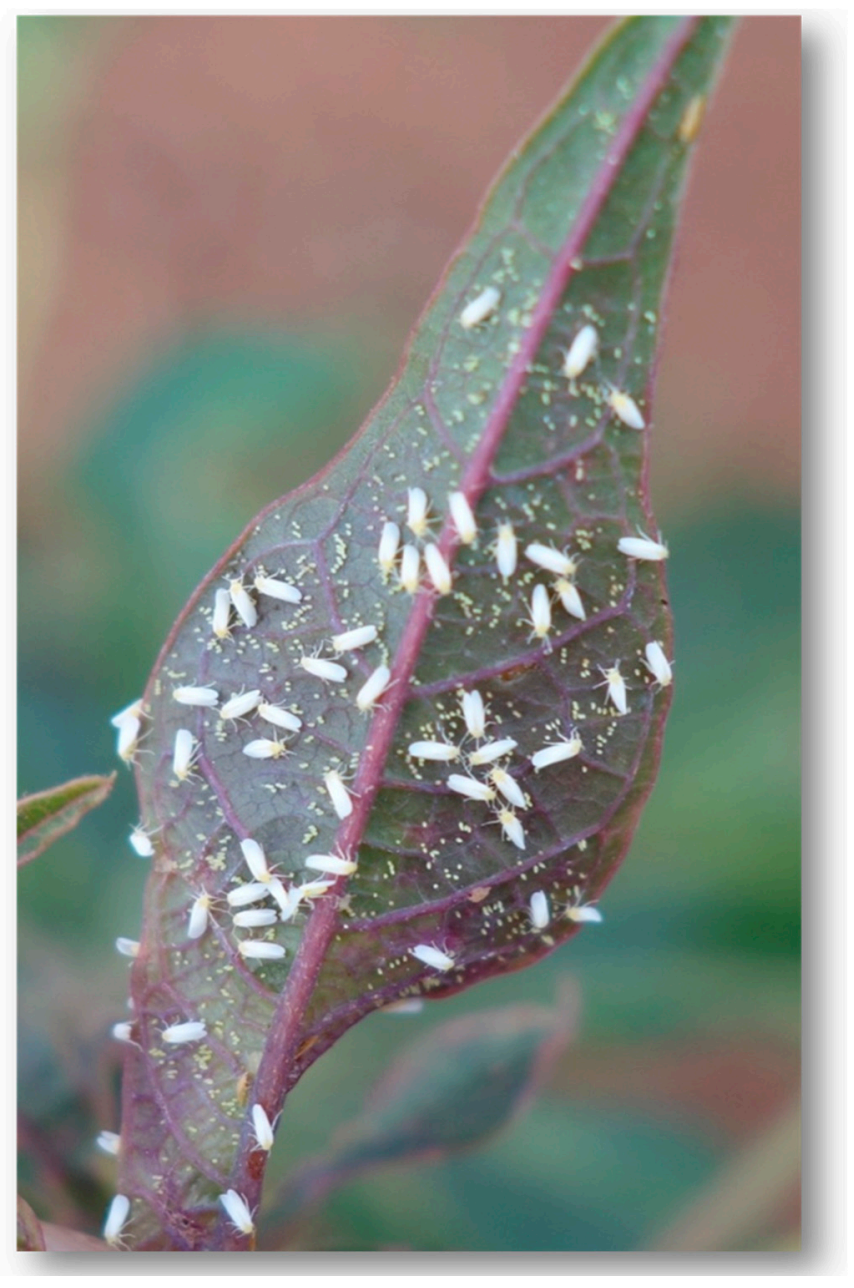

Figure 1. Bemisia tabaci SSA1 species on cassava (Photo: Laura M. Boykin).

\subsection{Bemisia tabaci Species Complex}

The B. tabaci species complex is globally distributed and the putative species are named based on their geographic locations; Mediterranean; Middle East-Asia Minor 1; Middle East-Asia Minor 2; Indian Ocean; Asia I; Australia/Indonesia; Australia; China; China 2; Asia II 1; Asia II 2; Asia II 3; Asia II 4; Asia II 5; Asia II 6; Asia II 7; Asia II 8; Italy; sub-Saharan Africa 1 (SSA1); sub-Saharan Africa 2 (SSA2); sub-Saharan Africa 3 (SSA3); sub-Saharan Africa 4 (SSA4); sub-Saharan Africa 5 (SSA5); New World; and Uganda [8]. Recent studies have reported new species (Asia II 9, Asia II 10, Asia III, and China 3, and Asia I-India and New World 2), for a total number of 34 morphologically [24] indistinguishable species reported in the B. tabaci complex [25-27]. The worldwide spread of emerging species, such as B. tabaci MEAM1, also known as B. argentifolii, and a Bemisia tabaci MED, continue to cause severe crop losses which will likely continue to increase, resulting in higher pesticide use on many crops (tomato, beans, cassava, cotton, cucurbits, potato, sweet potato). In East Africa, there are two distinct cassava-associated B. tabaci putative species, sub-Saharan Africa 1 (SSA1) and sub-Saharan Africa 2 (SSA2) [28]. In Kenya, limited studies on B. tabaci have been carried out in Eastern, Coastal Kenya, Nyanza, and the Western regions of Kenya, and the putative B. tabaci species found to be widely spread among the affected crops [29] remain elusive. 


\subsection{Host Range}

Bemisia tabaci is a polyphagous species, and some species are extremely polyphagous. They colonize mainly annual, herbaceous plants including over 500 species from 74 families $[1,30]$. B. tabaci is known to have a host range that is highly variable. Examples of the wide host range include avocado, banana, cabbage, capsicum, cassava, cauliflower, citrus, coconut, cotton, eggplant, garlic, guava, legumes, mango, mustard, onion, peachy, pepper, radish, squash, soybean, tomato, and tobacco [18]. However, species of B. tabaci vary with respect to geography, fecundity, dispersal behaviour, insecticide resistance, natural enemy complex, invasive behaviour, plant virus transmission, and complement endosymbionts [30]. In West Africa and Uganda, differences in host selection has been documented among different $B$. tabaci species [20].

\subsection{Species Molecular Markers}

In molecular genetics analysis, molecular markers have been used to study insect populations and determine phylogenetic relationships. The markers have been used to examine protein-coding genes, major ribosomal RNA genes, and non-coding regions [5,31]. The mitochondrial (mtCOI) DNA marker is the most commonly used, but other markers have also been used-for example, the ribosomal RNAs [32] and a ribosomal nuclear marker of the internal transcribed spacer I (ITSI) region sequences [33]. These markers have the advantage of relative ease of isolation and amplification and are amenable to straightforward analyses. Mitochondrial cytochrome oxidase I (mtCOI) has the highest degree of variability for the $B$. tabaci species compared to the nuclear genes mentioned above, therefore becoming the most widely used marker for phylogenetic studies of $B$. tabaci globally [31,34]; $\mathrm{mtCOI}$ has also been sequenced in many different orders of insects. The mitochondrial cytochrome oxidase I (mtCOI) marker [35] and (ITSI) region sequences $[33,36]$ have also been used to study the genetic variability and evolutionary relationships among $B$. tabaci from different geographical locations and host-plant species [26].

\section{Materials and Methods}

\subsection{Whitefly Collection}

The study was conducted in major cassava producing areas of Kenya from 2013 to November 2015. The regions of survey were as follows; Bungoma, Busia, Kakamega, Homabay, Migori, Kisumu, Siaya, Kilifi, Kwale, Taita Taveta, Nyamira, Kitui, and Machakos counties (Table 1). These geographical locations share a similar agro-ecology, where western region counties of Kenya are characterized by bimodal rainfall ranging from 950 to $1500 \mathrm{~mm}$ annually, temperature ranging from 18.4 to $25.4{ }^{\circ} \mathrm{C}$, altitude ranges of $900-1800 \mathrm{~m}$, and a savannah grassland. In the Eastern region, the altitude ranges from $1000 \mathrm{~m}$ to $1800 \mathrm{~m}$, with a similar rainfall potential of $500-760 \mathrm{~mm}$ as the hot and dry coastal hinterland [37]. The Coast region has rainfall ranging from 500 to $1000 \mathrm{~mm}$ annually, temperature ranges between 22.4 and $30.3^{\circ} \mathrm{C}$, altitude ranges of $900-1800 \mathrm{~m}$, and a savannah grassland. In each of the regions, 12 fields were randomly selected approximately $10 \mathrm{~km}$ apart. In each field, plants were assessed for whitefly populations along X-shaped transects [5]. In all the sites surveyed, adult whiteflies were collected from the five top most cassava leaves from ventral surfaces using an aspirator. Collected adult whiteflies were preserved in $70 \%$ ethanol and stored at $-20{ }^{\circ} \mathrm{C}$ in sampling bottles until analysis in the laboratory $[5,38]$. 
Table 1. Summary B. tabaci collected in Kenya and used in this study. These data are also mapped onto Figure 2, and there is an interactive map found at http://beta.whiteflybase.org/datamap/.

\begin{tabular}{|c|c|c|c|c|c|c|c|}
\hline $\begin{array}{l}\text { Sample } \\
\text { Number }\end{array}$ & County & Area & Field & Geographic Location & Altitude & $\begin{array}{l}\text { Genetic } \\
\text { Group }\end{array}$ & $\begin{array}{c}\text { Accession } \\
\text { No. }\end{array}$ \\
\hline 1 & Siaya & Ligega & NF3 & N00.20321, E034.27061 & 1330 & SSA-B & KY523872 \\
\hline 2 & Siaya & Sega & NF4 & N00.27314, E034.22346 & 1243 & SSA-D & KY523885 \\
\hline 3 & Siaya & Gem & NF5 & N00.03174, E034.25409 & 1957 & SSA-B & KY523894 \\
\hline 4 & Siaya & Karapul & NF8 & N00.05285, E034.30654 & 3132 & SSA-E & KY523892 \\
\hline 5 & Kisumu & Nyahera & NF2 & S00.03051, E034.71960 & 1459 & SSA-B & KY523852 \\
\hline 6 & Siaya & Kochieng & NF10 & N00.09266, E034.23024 & 1256 & SSA-B & KY523854 \\
\hline 7 & Siaya & Alego & NF14 & N00.04531, E034.37395 & 1409 & SSA-B & KY523870 \\
\hline 8 & Kisumu & Kit mikayi & $\mathrm{NF} 22$ & S00.10358, E034.57415 & 1176 & SSA-B & KY523855 \\
\hline 9 & Siaya & Barwino & NF16 & S00.09508, E034.29937 & 1509 & SSA-B & KY523853 \\
\hline 10 & Homabay & Koderobaro & NF33 & S00.78241, E034.59921 & 1416 & SSA-B & KY523871 \\
\hline 11 & Migori & Bukira West & NF34 & S01.23.442, E034.49201 & 2363 & SSA-E & KY523887 \\
\hline 12 & Homabay & Kokwanyo & NF27 & S00.42202, E034.78882 & 1275 & SSA-B & KY523875 \\
\hline 13 & Busia & Chakol & WF12 & N00.52575, E034.16062 & 1152 & SSA-D & KY523877 \\
\hline 14 & Busia & Asing'e & WF13 & N00.54886, E034.17672 & 1152 & SSA-C & KY523880 \\
\hline 15 & Busia & Aktesi & WF14 & N00.56531, E034.18919 & 1153 & SSA-B & KY523886 \\
\hline 16 & Busia & Kaina & WF17 & N00.62388, E034.25398 & 1177 & SSA-D & KY523876 \\
\hline 17 & Busia & Ang'orai & WF18 & N00.69299, E034.37015 & 1230 & SSA-B & KY523879 \\
\hline 18 & Busia & Kasing'e & WF19 & N00.71344, E03434693 & 1393 & SSA-C & KY523881 \\
\hline 19 & Bungoma & Kimwanga & WF26 & N00.59644, E034.44701 & 1233 & SSA-A & KY523874 \\
\hline 20 & Taita Taveta & Wundanyi & CF30 & S03.39443, E038.36485 & 1339 & SSA-B & KY523882 \\
\hline 21 & Homabay & Mawego & NF31 & S0038946, E034.77587 & 1424 & SSA-D & KY523888 \\
\hline 22 & Migori & Kiomakebe & NF40 & S01.21158, E034.53714 & 1562 & SSA-B & KY523895 \\
\hline 23 & Migori & Kehancha & NF41 & S01.11733, E034.52141 & 1418 & SSA-B & KY523856 \\
\hline 24 & Nyamira & Borabu & NF44 & S00.72273, E035.00735 & 1926 & SSA-B & KY523864 \\
\hline 25 & Kilifi & Kikambala & CF1 & S03.86207, E039.74467 & 86 & SSA-B & KY523858 \\
\hline 26 & Kilifi & Mitangoni & CF5 & S03.69020, E039.77895 & 61 & SSA-B & KY523860 \\
\hline 27 & Kilifi & Ngerenya & CF7 & S03.54610, E039.83553 & 53 & SSA-B & KY523861 \\
\hline 28 & Kilifi & Mkongani & CF9 & S03.39686, E039.91546 & 20 & SSA-B & KY523878 \\
\hline 29 & Kilifi & Mtwapa(KARLO) & CF12 & S03.93400, E039.73534 & 38 & SSA-B & KY523884 \\
\hline 30 & Kwale & Ngombeni & CF13 & S04.12535, E039.63130 & 25 & SSA-B & KY523862 \\
\hline 31 & Kwale & Tsunguni & CF15 & S04.18433, E039.55974 & 115 & SSA-B & KY523867 \\
\hline 32 & Kwale & Shamu & CF17 & S04.30154, E039.54972 & 42 & SSA-B & KY523891 \\
\hline 33 & Kwale & Diani & CF18 & S04.30731, E039.51998 & 90 & SSA-B & KY523865 \\
\hline 34 & Kwale & Shimba hills & CF19 & S04.35600, E039.42932 & 104 & SSA-B & KY523869 \\
\hline 35 & Kwale & Kilulu & CF21 & S04.39463, E039.35639 & 85 & SSA-B & KY523890 \\
\hline 36 & Kwale & Kikoneni & CF22 & S04.42855, E039.31791 & 70 & SSA-B & KY523868 \\
\hline 37 & Kwale & Lungalunga & CF25 & S04.53264, E039.14732 & 64 & SSA-B & KY523866 \\
\hline 38 & Kwale & Kingwende & CF27 & S04.48550, E039.45035 & 22 & SSA-B & KY523863 \\
\hline 39 & Taita Taveta & Mwatate & CF28 & S03.48400, E038.38088 & 830 & SSA-B & KY523889 \\
\hline 40 & Taita Taveta & Mbogoni & CF36 & S03.41414, E037.70263 & 729 & SSA-B & KY523883 \\
\hline 41 & Taita Taveta & Taveta & CF37 & S03.46017, E037.69030 & 720 & SSA-B & KY523859 \\
\hline 42 & Kitui & Kalimani & EF18 & S01.31211, E037.95479 & 1232 & SSA-B & KY523893 \\
\hline 43 & Kitui & Wakulili & EF25 & S01.42728, E037.99684 & 1135 & SSA-B & KY523857 \\
\hline 44 & Machakos & Musiini & $\mathrm{EF} 4$ & S01.42061, E037.36724 & 1413 & SSA-B & KY523873 \\
\hline
\end{tabular}

\subsection{DNA Extraction}

Individual adult whiteflies preserved in ethanol were selected, washed in distilled water, and dried on filter paper for few seconds. They were then immediately and thoroughly macerated with a micropestle in a $0.5 \mathrm{~mL}$ Eppendorf tube containing $50 \mu \mathrm{L}$ of STE buffer $(0.1 \mathrm{M} \mathrm{NaCl}, 10 \mathrm{mM}$ Tris- $\mathrm{HCl}$, $\mathrm{pH}$ 8.0, 1.0 mM EDTA). There was an addition of proteinase $\mathrm{K}$ to the STE buffer. The lysis product was incubated for $15 \mathrm{~min}$ at a temperature of $65^{\circ} \mathrm{C}$, and then further heat treated at $95^{\circ} \mathrm{C}$ for $10 \mathrm{~min}$. The lysis product was centrifuged briefly for $5 \mathrm{~min}$ at $10,000 \mathrm{rpm}$ at $4{ }^{\circ} \mathrm{C}$ and immediately placed on ice before PCR amplification. Proteinase K was added with a slight modification of this protocol [39]. 


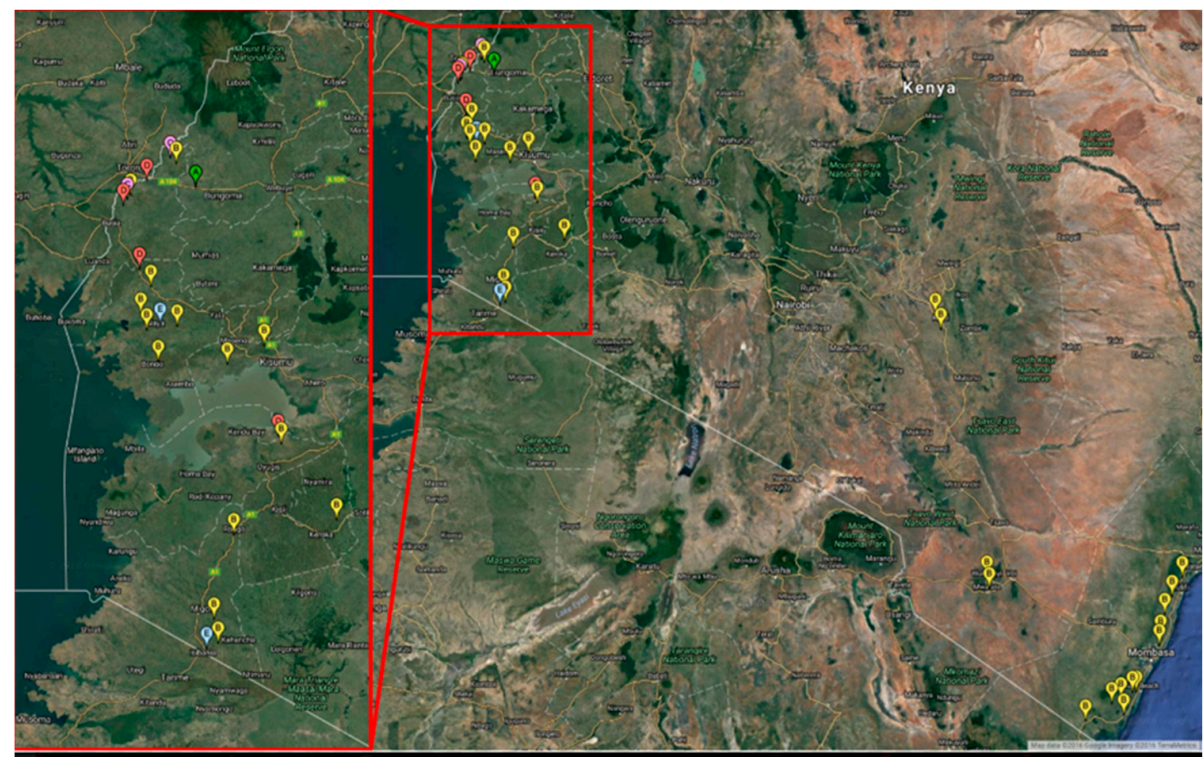

Figure 2. Map of Kenya showing distribution of cassava whiteflies included in this study. The red box highlights the collection sites near Lake Victoria, and the red box to the left is a blow-up of that region. The different coloured circles with letters represent the five different clades Bemisia tabaci species (A-E or SSA-A-E) as indicated in Table 1 in the column labelled "Genetic Group".

\subsection{PCR Amplification of mtCOI DNA}

A total of 44 sample sites were collected based on the description above. These collections were used to study the genetic diversity (by extracting DNA from individual whiteflies from each sample collection) and their distribution in the various cassava growing zones in Kenya. Polymerase Chain Reaction was conducted using two primers; MT10/C1-J-2195 (5'-TTGATTTTTTGG TCATCCAGAAGT-3') and MT12/L2-N-3014 (5'-TCCAATGC ACTAAT-CTGCCATATTA-3), to amplify mitochondria cytochrome oxidase I (mtCOI) DNA. All reactions contained $25 \mu \mathrm{L}$ of $0.15 \mu \mathrm{L}$ of $60 \mathrm{ng} / \mu \mathrm{L}$ of DNA, $0.5 \mu \mathrm{L}$ of each primer $10 \mu \mathrm{m} / 10$ pmole, $0.2 \mu \mathrm{L}$ of Taq DNA polymerase, $5 \mu \mathrm{L}$ of $5 \times$ MyTaq Reaction buffer, $5.0 \mu \mathrm{L}$ of DNA template (5xTaq Master enhancer), and topped with $13.80 \mu \mathrm{L}$ nuclease free water. The contents in the microtube were vortexed briefly and quickly spun. Initial denaturation of template DNA was conducted for $3 \mathrm{~min}$ followed by 30 cycles of denaturation at $94{ }^{\circ} \mathrm{C}$ for $30 \mathrm{~s}$, primer annealing at $52{ }^{\circ} \mathrm{C}$ for $30 \mathrm{~s}$, and extension at $72{ }^{\circ} \mathrm{C}$ for $1 \mathrm{~min}$. The final extension of $10 \mathrm{~min}$ was run at $72{ }^{\circ} \mathrm{C}$ and the reaction held at $4{ }^{\circ} \mathrm{C}$ in a Perkin Elmer DNA thermal cycler [35].

\subsection{Gel Electrophoresis and DNA Sequencing}

The PCR products were electrophoresed in $2 \%$ Agarose gel stained in ethidium bromide in $1 \times$ Tris acetate ethylenediaminetetraacetic acid (TAE) buffer and the amplified DNA was visualized under UV transilluminator and photographed using an Electrophoresis Documentation and Analysis System 120 digital camera [5]. PCR products of the expected size $(850 \mathrm{bp})$ were obtained. Bands were excised from the agarose gel and purified using a Qiagen gel Purification kit (QIAGEN Inc, San Diego, CA, USA) as per the manufacturer's procedure [8]. Sequencing was outsourced, and done bi-directionally using the amplification primers. The sequences of COI were submitted to GenBank using Bankit, a web-based data submission tool [40].

\subsection{Phylogenetic Analysis of mtCOI Sequences}

B. tabaci mtCOI sequences were edited manually using DNA MAN programme to produce a consensus sequence ( $\sim 850 \mathrm{bp}$ ) for each individual adult whitefly. The edited consensus sequences were aligned using the Clustal W (weighted) [41] MrBayes version 3.2.1 [42] that employs Markov Chain 
Monte Carlo (MCMC) sampling to approximate the posterior probabilities of phylogenies [43]; the posterior probabilities are shown above the branches (Figure 3). MrBayes 3.2.1 was run in parallel on the Magnus supercomputer (located at Pawsey Supercomputer Centre, Perth, Western Australia) utilising the BEAGLE library [44]. MrBayes 3.2.1 was run with a GTR + I + G model of molecular evolution, utilizing four chains for 30 million generations and trees were sampled every 1000 generations. All runs reached a plateau in likelihood score, which was indicated by the standard deviation of split frequencies (0.0015), and the potential scale reduction factor (PSRF) was close to one, indicating that the MCMC chains converged.

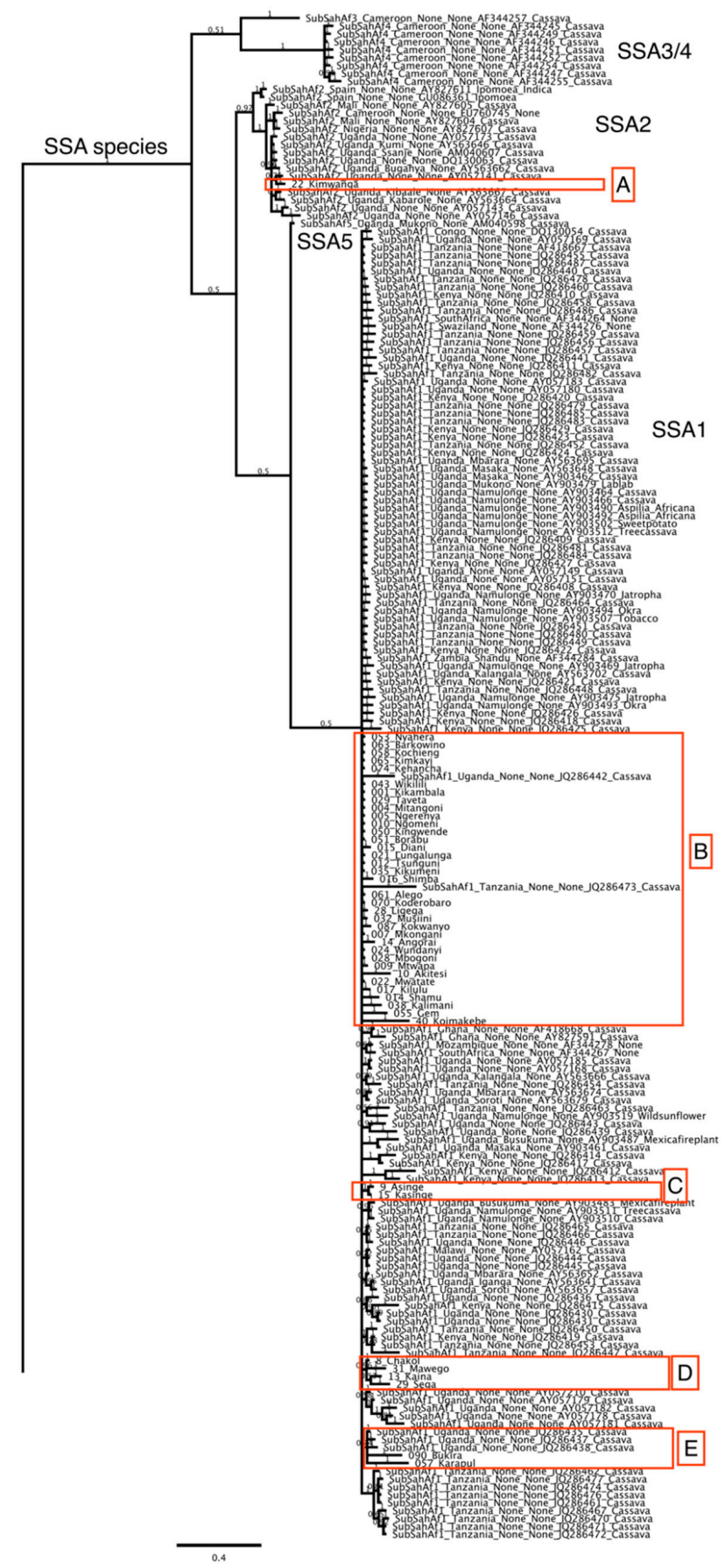

Figure 3. Entire MrBayes phylogenetic tree based on the mitochondrial cytochrome oxidase I sequence for B. tabaci collected in Kenya. Figure A1. (a-c) Distinct clades A-E blown up below with new sequences generated in this study highlighted in green. 


\section{Results}

\section{Distribution of Bemisia tabaci Putative Species on Cassava in Kenya}

Amplification of the mtCO1 gene resulted in an $850 \mathrm{bp}$ fragment (Figure 4) for each adult whitefly using pair primers MT10 and MT12. A consensus sequence from both forward and reverse sequencing was obtained for the 44 individual whiteflies. The 44 new mtCOI sequences from this study were combined with other mtCOI sequences from global whitefly samples found in www.whiteflybase.org. The final dataset was composed of 659 sequences and was trimmed to $650 \mathrm{bp}$. The results of the current study indicate the distribution of two different Bemisia tabaci sub-Saharan Africa species circulating in Kenya (Figure 3). The putative species [45] found in our study are from the sub-Saharan Africa species SSA1 and SSA2, in which five distinct clades were identified and labelled (clades A-E) (Table 1 and Figure 2). The first clade (A) can be compared to the SSA2 putative species [25] with sequence similarity of $99.5 \%$ which was also referred to as the "invader" [28]. According to Legg et al. [28] SSA2 is frequently found in western Kenya and is an invasive vector in cassava growing areas which is associated with increased incidences of CMD in various geographical regions of East Africa [46]. The geographic distribution of the species found in Kenya is intriguing. Only SSA-B was found at the coast while around Lake Victoria there were four different genetic entities (SSA-A, B, C, D) identified (Figure 3 and Table 2). The second clade (B) clustered with other $B$. tabaci sequences that have sequence similarity (97\%-98.8\%) from throughout east and southern Africa [47] (Figure 3). Thirdly, clade C specimens were collected from one county, Busia, and two samples from the region form a unique clade to Kenya not found before in previous sampling efforts in the region. Fourthly, clade D, sampled from counties surrounding the Lake Victoria Basin and from Busia, is also unique to Kenya. Finally, the last clade (E) clustered with the sub-Saharan Africa (SSA1) based upon considering previously published sequences from southern Uganda [28].

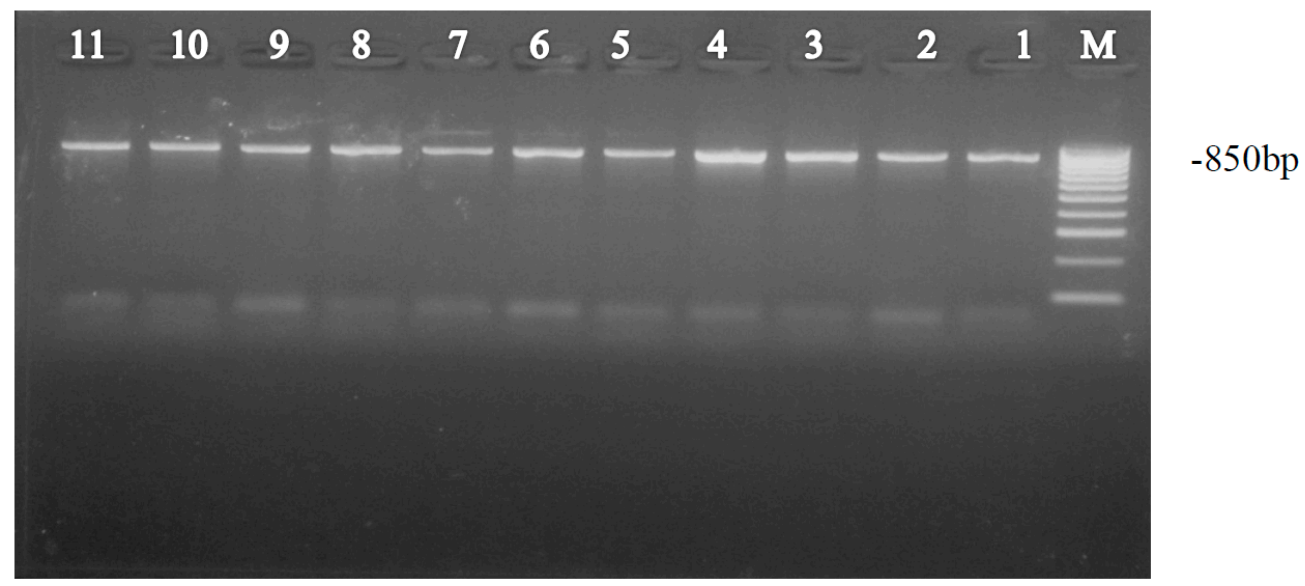

Figure 4. Polymerase chain reaction-amplified product ( $850 \mathrm{bp})$ of B. tabaci.

Table 2. Geographic distribution of the five distinct clades of whiteflies found in Kenya. SSA-A-E corresponds to the clades found in Figure 3.

\begin{tabular}{ccccccc}
\hline Location in Kenya & Number of Samples & SSA-A & SSA-B & SSA-C & SSA-D & SSA-E \\
\hline Western/Lake & 7 & 1 & 2 & 2 & 2 & - \\
Nyanza & 16 & - & 12 & - & 2 & 2 \\
Eastern & 3 & - & 3 & - & - & - \\
Coast & 18 & - & 18 & - & - & - \\
\hline
\end{tabular}




\section{Discussion}

Using the mtCOI gene as a molecular marker, our study determined the occurrence of two Bemisia tabaci species belonging to five distinct clades within the sub-Saharan Africa (SSA1 and SSA2) species (Table 2). SSA-B is the most abundant clade found in Kenya and is widely distributed along the coast of Kenya and around the Lake Victoria basin area. This corresponds to where cassava is grown in Kenya [9]. The nature of the agroecological zones where cassava is grown in Kenya is hot and humid [36], which also supports many other crops that become alternative hosts of whiteflies, such as sweet potato and tomato, thereby increasing the spread of the vector and transmission of viral diseases in cassava. Whitefly collections from cassava fields (three to six months) from major cassava growing areas in Kenya have a close relationship with the virus diseases that are widely distributed in different agro-ecological zones (low, medium, and high altitude at less or greater than $1000 \mathrm{~m}$ above sea level [14]. The Lake Victoria Basin climate is an equatorial climate with temperatures modified by the relatively high elevation of the mountains surrounding the basin, such as Mt. Elgon. Temperatures and rainfall are lower than the typical equatorial conditions to be classified as a sub-humid climate (temperature range between $20^{\circ} \mathrm{C}$ to over $35^{\circ} \mathrm{C}$ ). The rainfall ranges between $1000 \mathrm{~mm}$ and $1500 \mathrm{~mm}$ with no distinct dry season in the year, thereby creating a favourable atmosphere for SSA whiteflies to spread throughout the lake basin and riparian states. However, along the coast, the climatic conditions are quite different thereby highlighting the diverse habitat SSA-B can inhabit. CMD and CBSD are both cassava virus pandemics that cause $100 \%$ loss to cassava preproduction in most parts of East Africa [46]. There is continued spread of CBSD in most areas of East Africa affected by CMD, probably because of large populations of $B$. tabaci during the early planting seasons when the rains are available [11].

In terms of CBSD, the coast is reported to be the original epidemic zone of CBSD, while the Great Lakes regions are the most recent epidemic zone [48]. One hypothesis is that the native range of SSA-B is along the coast in Kenya and appears to be displacing the local species of Nyanza and the Western regions by invading these new areas. The alternative hypothesis is that SSA-B originated in the Lake zone and has been moved to the coast via the movement of cuttings that could potentially be infested with whitefly nymphs. To test these hypotheses, a thorough population genetics study is needed to detect migration patterns of SSA-B. There are other members of the $B$. tabaci complex that are also widespread and invasive. For example, it has been reported that in many parts of the world there has been an explosive outbreak of $B$. tabaci species in the tropics and sub-tropic regions, where species B. tabaci MEAM1 and B. tabaci MED are extremely polyphagous [30]. These species have the ability of exhibiting resistance to many insecticides, high fecundity, and the capability to displace their competitors [49]. Through close monitoring of B. tabaci MEAM1, it has been observed to cause significant losses through its ability to rapidly expand its population, transmit Geminiviruses, and overcome the effects of insecticides [50]; the same could be true for SSA-B.

In addition, Figure A1c shows that clades $C$ and D of $B$. tabaci are unique and are spread around Lake Victoria Basin of Kenya and Uganda where the cassava crop is highly affected by the CMD and CBSD epidemics. Work done on the epidemiology of both CMD and CBSD in most parts of East Africa is associated with the presence of $B$. tabaci [51], however, most previous studies have failed to correctly characterize the species of $B$. tabaci found. Clade $C$ can only be found in one locality in Busia county away from the Lake Victoria Basin region (Figure 2). The viral diseases are rapidly spread from plant to plant and between fields by the whitefly vectors, $B$. tabaci, and producing the phenomenon of a spreading severe disease "front" that advanced through the southern part of Uganda and to the neighbouring countries [11]. The phylogenetic analysis of the whiteflies in Kenya indicates the occurrence of five different clades of $B$. tabaci from the surveyed areas, which suggests close relationships within the cryptic species complex as well as the evolutionary history within the riparian states of East Africa [52].

In the past, clade A (SSA2) was a major genetic group prevalent in areas affected greatly by the CMD pandemic that most recently has been reported to be absent from cassava collections in Uganda $[8,12,31]$ and in western Kenya [8,44]. This study reports the detection of SSA2 in western 
Kenya along the boundary of Kenya and Uganda. SSA2 is referred to as an invasive whitefly species "invader/Ug2" that is associated with areas that are severely affected by CMD in Uganda [53,54]. The putative species SSA2 most probably moved from Uganda to Kenya through exchange of infested cassava planting materials and/or environmental influences, such as the effect of strong winds.

There are many viral species and many whitefly species circulating in East Africa. The causal viruses of CMD are: African cassava mosaic virus-Kenya (ACMV-K), and East African cassava mosaic virus (EACMV), East African cassava mosaic Zanzibar virus (EACMZV), Uganda variant strain of the EACMV (EACMV-Ug), and East African cassava mosaic Kenya Virus (EACMKV) and for cassava brown streak disease there are two recognized species, Cassava brown streak virus and Uganda cassava brown streak virus with many more being uncovered as more genomes are characterized [14,15]. The challenge now is to match these many viruses of CMD and CBSD with the many species in the Bemisia tabaci species complex. We can no longer assume the vector is "B. tabaci" as there are many species present in the region where these devastating viruses are circulating. All studies in the future must include barcoding of the vector they are finding in their survey data and the transmission studies.

\section{Conclusions}

In sub-Saharan Africa, cassava remains primarily a subsistence crop to farmers, but little attention has been directed to knowledge and significance on whitefly management on cassava, and this has led to high populations and continued spread of the vector and transmission of the virus diseases in cassava crops [11]. The notorious plant virus vector B. tabaci in Kenya is made of two species (SSA1 and SSA2) grouped into five distinct clades. The five clades have a less than $3.5 \%$ divergence in mtCOI [25], but they may differ in terms of their biology, fecundity, virus transmission, and mating ability [8], and, as such, further biological studies are needed. In addition, the SSA2 putative species requires further investigation of its role in cassava virus disease epidemiology.

Acknowledgments: The authors wish to thank the Bill and Melinda Gates Foundation through the Mikocheni Agricultural Research Institute for financially supporting this work within the framework of the Cassava Viruses Diagnostics Project (Grant No. OPP1052391). Special thanks go to Samuel Mwaura and Timothy Onyinge for invaluable technical support in molecular laboratory analysis. Data analysis work was supported by resources provided by the Pawsey Supercomputing Centre with funding from the Australian Government and the Government of Western Australia. We thank Anders Savill for generating Figure 2.

Author Contributions: Duke M. Manani, Elijah M. Ateka, Steven R. G. Nyanjom, and Laura M. Boykin conceived and designed the experiments; Duke M. Manani, Elijah M. Ateka, Steven R. G. Nyanjom, and Laura M. Boykin performed the experiments; Duke M. Manani, Elijah M. Ateka, Steven R. G. Nyanjom, and Laura M. Boykin analysed the data; Duke M. Manani, Elijah M. Ateka, Steven R. G. Nyanjom, and Laura M. Boykin contributed reagents/materials/analysis tools; Duke M. Manani, E Elijah M. Ateka, Steven R. G. Nyanjom, and Laura M. Boykin wrote the paper.

Conflicts of Interest: The authors declare no conflict of interest.

\section{Appendix A}

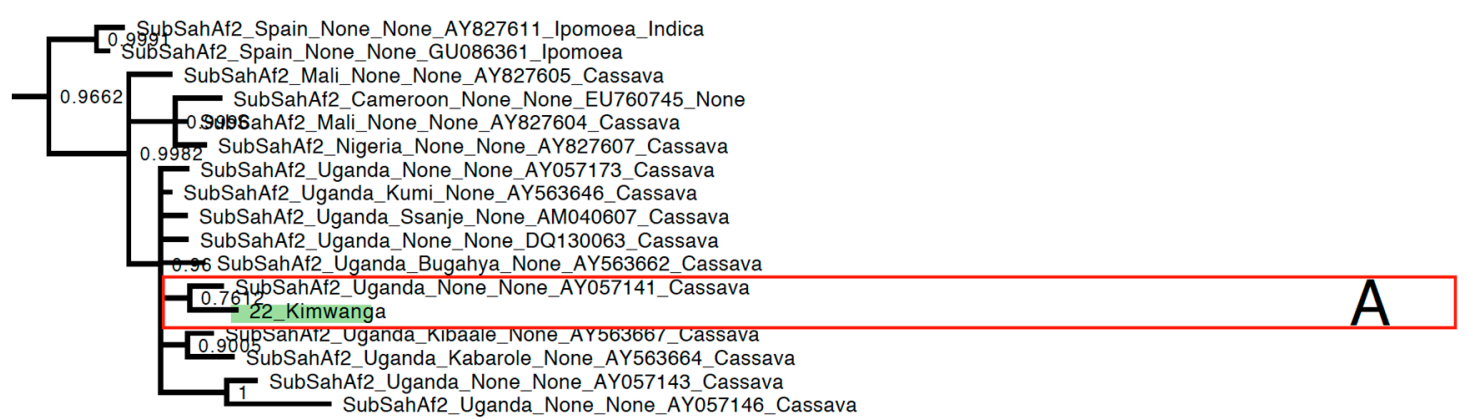

(a) Clade a

Figure A1. Cont. 


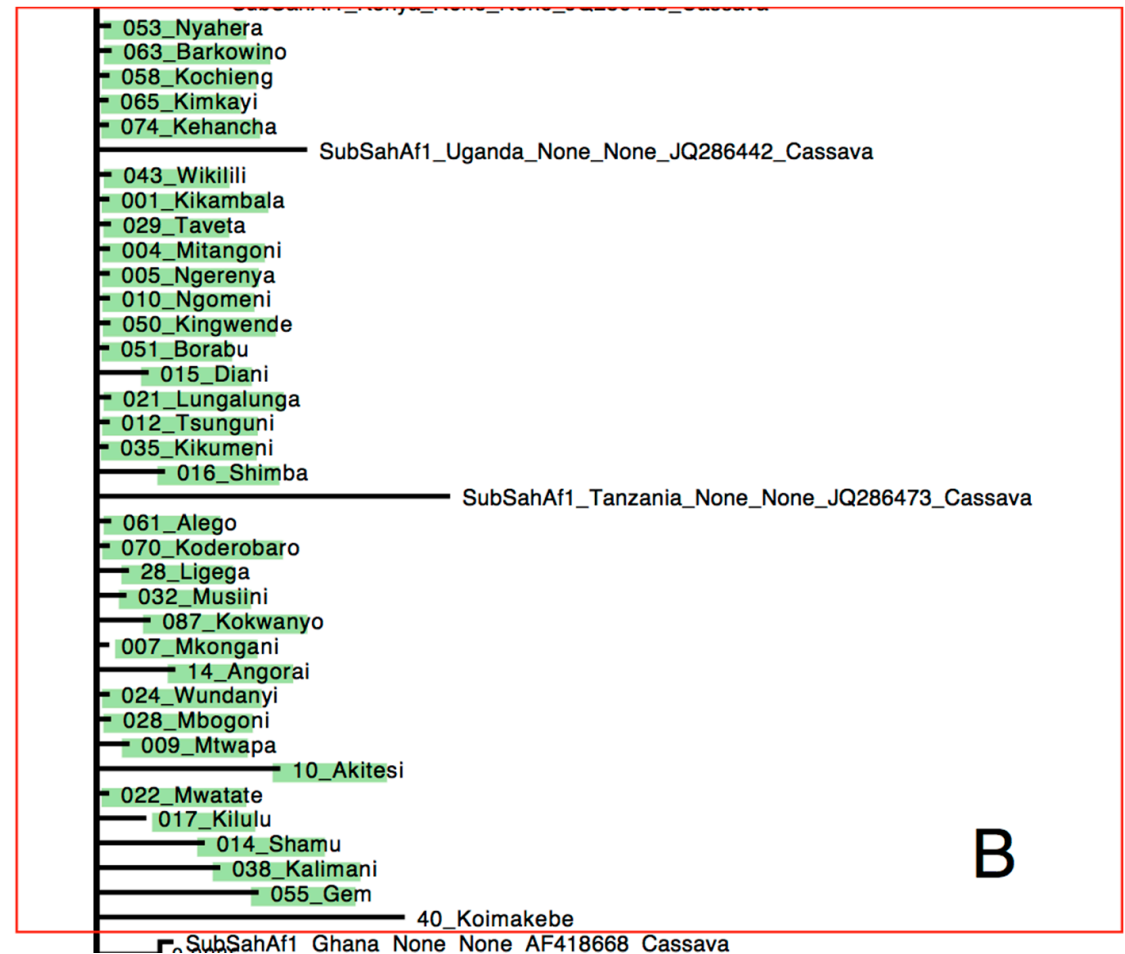

(b) Clade b

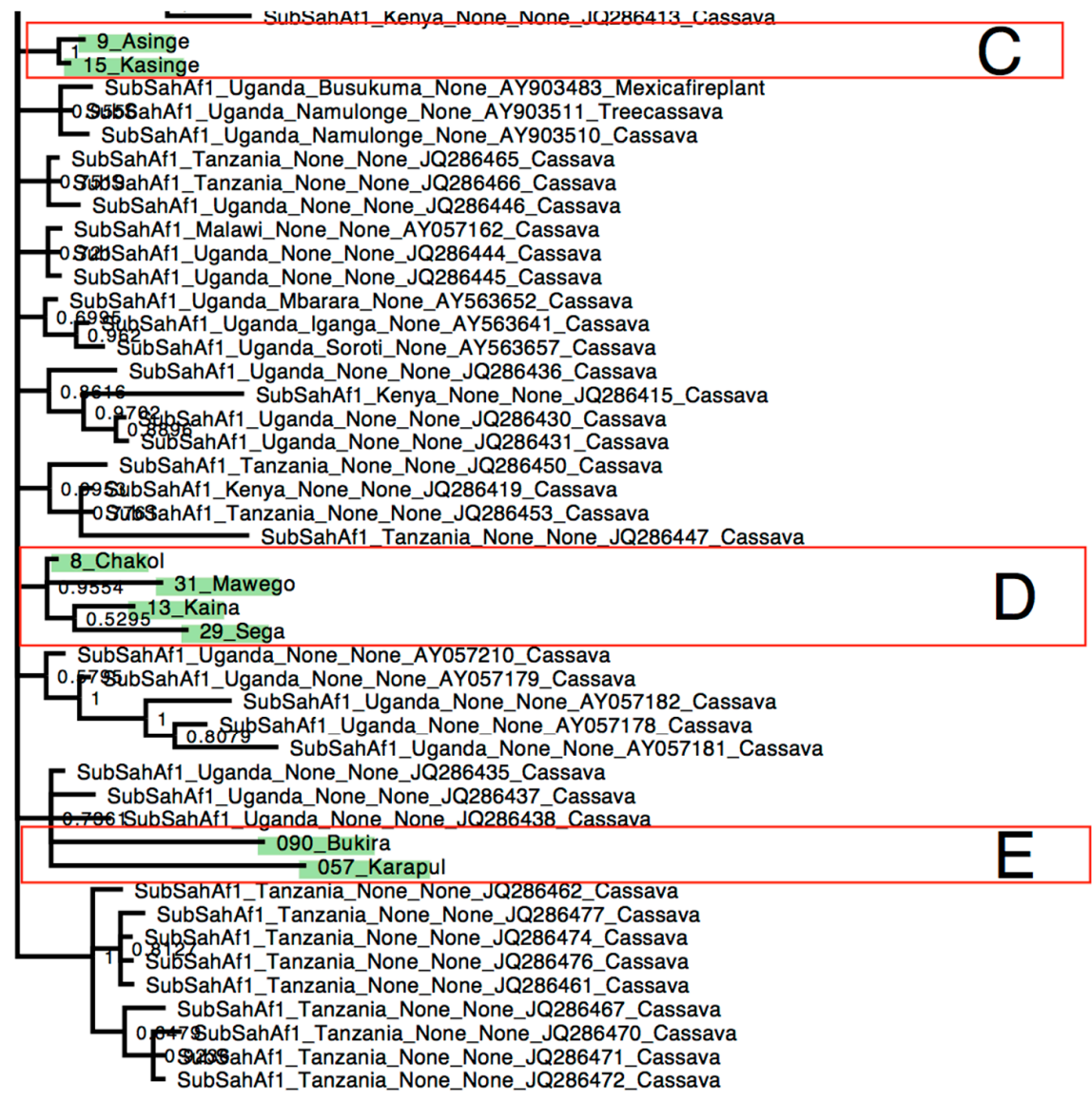

(c) Clade c

Figure A1. $(\mathbf{a}-\mathbf{c})$ : Distinct clades A-E blown up below with new sequences generated in this study highlighted in green. 


\section{References}

1. Cossa, N.S. Epidemiology of Cassava Mosaic Disease in Mozambique. Ph.D. Thesis, University of Witwatersrand, Johannesburg, South Africa, 2011.

2. Nweke, F.I. A Cash Crop in Africa. COSCA Working Paper No. 14. In Collaborative Study of Cassava in Africa; International Institute of Tropical Agriculture: Ibadan, Nigeria, 1996.

3. Mwango'mbe, A.W.; Mbugua, S.K.; Olubayo, F.O.; Ngugi, E.K.; Mwinga, R.; Munga, T.; Muiru, W.M. Challenges and Opportunities in Cassava Production among the Rural Households in Kilifi County in the Coastal Region of Kenya. J. Biol. Agric. Healthc. 2013, 3, 30-35.

4. Were, H.K.; Winter, S.; Maiss, E. Characterisation and distribution of cassava viruses in Kenya. Afr. Crop Sci. Conf. Proc. 2007, 8, 909-912.

5. Sseruwagi, P. Molecular variability of cassava Bemisia tabaci and its effects on the epidemiology of cassava mosaic Geminiviruses in Uganda. Ph.D. Thesis, University of Witwatersrand, Johannesburg, South Africa, 2005.

6. Wyatt, S.D.; Brown, J.K. Detection of subgroup III Geminivirus isolated in leaf extracts by degenerate primers and polymerase chain reaction. Phytopathology 1996, 86, 1288-1293. [CrossRef]

7. International Institute of Tropical Agriculture. Preemptive Management of the Virulent Cassava Mosaic Disease through an Integrated Cassava Development Approach for Enhanced Rural Sector Economy in the South-South and South-East Zones of Nigeria; International Institute of Tropical Agriculture: Ibadan, Nigeria, 2003.

8. Mugerwa, H.; Marie, E.C.; Alicai, T.; Ateka, E.; Atuncha, H.; Ndunguru, J.; Sseruwagi, P. Genetic Diversity and Geographic Distribution of Bemisia tabaci (Gennadius) (Hemiptera: Aleyrodidae) Genotypes Associated with Cassava in East Africa. Ecol. Evol. 2012, 2, 2749-2762. [CrossRef] [PubMed]

9. Simon, E.B.; Rob, W.B.; William, S.S.; Kahiu, N.; Markham, P.G.; John, S. Genetic diversity and phylogeography of cassava mosaic viruses in Kenya. J. Gen. Virol. 2006, 87, 3053-3065.

10. Aduwo, J.R.; Guy, A. Assessing the Performance of two Artificial Neural Networks in the Classification of Cassava Mosaic Disease. Available online: http://cit.mak.ac.ug/iccir/downloads/ICCIR_10/Jennifer\% 20ose\%20Aduwo\%20and\%20Acellam\%20Guy.pdf (accessed on 13 September 2016).

11. Legg, P.J.; Shirima, R.; Tajebe, S.L.; Guastella, D.; Boniface, S.; Jeremiah, S.; Nsami, E.; Chikoti, P.; Rapisarda, C. Biology and management of Bemisia whitefly vectors of cassava virus pandemics in Africa. Pest Manag. Sci. 2014, 70, 1446-1453. [CrossRef] [PubMed]

12. Legg, J.P.; Sseruwagi, P.; Boniface, S.; Okao-Okuja, G.; Shirima, R.; Bigirimana, S.; Gashaka, G.; Herrmann, H.W.; Jeremiah, S.; Obiero, H.; et al. Spatio-temporal patterns of genetic change amongst populations of cassava Bemisia tabaci whiteflies driving virus pandemics in East and Central Africa. Virus Res. 2013, 186, 61-75. [CrossRef] [PubMed]

13. Legg, J.P.; Owor, B.; Sseruwagi, P.; Ndunguru, J. Cassava mosaic virus disease in East and Central Africa: Epidemiology and management of a regional pandemic. Adv. Virus Res. 2006, 67, 355-418. [PubMed]

14. Ndunguru, J.; Sseruwagi, P.; Tairo, F.; Stomeo, F.; Maina, S.; Djinkeng, A.; Kehoe, M.; Boykin, L.M. Analyses of Twelve New Whole Genome Sequences of Cassava Brown Streak Viruses and Ugandan Cassava Brown Streak Viruses from East Africa: Diversity, Supercomputing and Evidence for Further Speciation. PLoS ONE 2015, 10, e0139321.

15. Alicai, T.; Ndunguru, J.; Sseruwagi, P.; Tairo, F.; Okao-Okuja, G.; Nanvubya, R.; Kiiza, L.; Kubatko, K.; Kehoe, M.A.; Boykin, L.M. Cassava brown streak virus has a rapidly evolving genome: Implications for virus speciation, variability, diagnosis and host resistance. Sci. Rep. 2016. [CrossRef] [PubMed]

16. Ntawuruhunga, P.; Legg, J. New Spread of Cassava Brown Streak Virus Disease and its Implications for the Movement of Cassava Germplasm in the East and Central African Region. Available online: http:/ / citeseerx. ist.psu.edu/viewdoc/download?doi=10.1.1.547.7713\&rep=rep1\&type=pdf (accessed on 13 September 2016).

17. Mohammed, I.U.; Abarshi, M.M.; Muli, B.; Hillocks, R.J.; Maruthi, M.N. The Symptom and Genetic Diversity of Cassava Brown Streak Viruses Infecting Cassava in East Africa. Adv. Virol. 2012. [CrossRef] [PubMed]

18. Palaniswami, M.S.; Henneberry, T.J. Bemisia tabaci (Genn.): Biotypes and Cassava Mosaic Virus in India. In The Whitefly, Bemisia tabaci (Homoptera: Aleyrodidae) Interaction with Geminivirus-Infected Host Plants; Springer: Houten, The Netherlands, 2011; pp. 121-163.

19. Martin, J.H. Whiteflies of Belize (Hemiptera: Aleyrodidae). Part 1: Introduction and account of the subfamilify Aleurodidae Quintance and Baker. Zootaxa 2004, 681, 1-119. 
20. Navas-Castillo, J.; Fiallo-Olive, E.; Sanchez-Campos, S. Emerging virus diseases transmitted by whiteflies. Annu. Rev. Phytopathol. 2011, 49, 219-248. [CrossRef] [PubMed]

21. Smith, H.A.; Seijo, E.T.; Vallad, E.G.; Peres, A.N.; Druffel, L.K. Evaluating Weeds as Hosts of Tomato yellow leaf curl virus. Environ. Entomol. 2015, 44, 1101-1107. [CrossRef] [PubMed]

22. Thompson, W.M.O. The Whitefly, Bemisia tabaci (Homoptera: Aleyrodidae) Interaction with Geminivirus-Infected Host Plants; Springer: Houten, The Netherlands, 2011.

23. Data sheets on quarantine organisms No. 178, Bemisia tabaci. Available online: https://www.eppo.int/ QUARANTINE/data_sheets/insects/BEMITA_ds.pdf (accessed on 13 September 2016).

24. Boykin, L.M.; Armstrong, K.F.; Kubatko, L.; de Barro, P. Species Delimitation and Global Biosecurity. Evol. Bioinform. 2012, 8, 1-37. [CrossRef] [PubMed]

25. Dinsdale, A.; Cook, L.; Riginos, C.; Buckley, Y.M.; De Barro, P. Refined Global Analysis of Bemisia tabaci (Hemiptera: Sternorrhyncha: Aleyrodoidea: Aleyrodidae) Mitochondrial Cytochrome Oxidase 1 to Identify Species Level Genetic Boundaries. Ann. Entomol. Soc. Am. 2010, 103, 196-208. [CrossRef]

26. Lee, W.; Park, J.; Lee, G.-S.; Lee, S.; Akimoto, S.-I. Taxonomic Status of the Bemisia tabaci Complex (Hemiptera: Aleyrodidae) and Reassessment of the Number of Its Constituent Species. PLoS ONE 2013, 8, e63817.

27. Boykin, L.M.; Barro, P.J.D. A practical guide to identifying members of the Bemisia tabaci species complex: And other morphologically identical species. Front. Ecol. Evol. 2014, 45, 1-5. [CrossRef]

28. Legg, J.P.; French, R.; Rogan, D.; Okao-Okuja, G.; Brown, J.K. A distinct, Bemisia tabaci (Gennadius) Hemiptera: Sternorrhyncha: Aleyrodidae) genotype cluster is associated with the epidemic of severe cassava mosaic virus disease in Uganda. Mol. Ecol. 2002, 11, 1219-1229. [CrossRef] [PubMed]

29. Riis, L.; Njuguna, T.; Raini, R.; Lohr, B.; Bob, M.A. Whiteflies and Whitefly-Borne Viruses in the Tropics; International Center of insect Physiology and ecology (ICIPE): Nairobi, Kenya, 2000.

30. Brown, J.K.; Frohlich, D.R.; Rosell, R.C. The sweetpotato or silverleaf whiteflies: Biotypes of Bemisia tabaci or a species complex? Ann. Rev. Entomol. 1995, 40, 511-534. [CrossRef]

31. Sseruwagi, P.; Maruthi, M.N.; Colvin, J.; Rey, M.; Brown, J.K.; Legg, J.P. Colonization of non-cassava plant species by cassava whiteflies (Bemisia tabaci) in Uganda. Entomol. Exp. Appl. 2006, 19, 145-153. [CrossRef]

32. Caterino, M.S.; Cho, S.; Sperling, F.A.H. The Current State Of Insect Molecular Systematics: A thriving Tower Of Babel. Ann. Rev. Entomol. 2000, 45, 1-54. [CrossRef] [PubMed]

33. De Barro, P.J. Genetic structure of the whitefly Bemisia tabaci in the Asia-Pacific region revealed using microsatellite markers. Mol. Ecol. 2005, 14, 3695-3718. [CrossRef] [PubMed]

34. Boykin, L.M.; Shatters, R.G., Jr.; Rosell, R.C.; McKenzie, C.L.; Bagnall, R.A.; De Barro, P. Global relationships of Bemisia tabaci (Hemiptera: Aleyrodidae) revealed using Bayesian analysis of mitochondrial COI DNA sequences. Mol. Phylogenet. Evol. 2007, 44, 1306-1319. [CrossRef] [PubMed]

35. Frohlich, D.R.; Torres-Jerez, I.; Bedford, I.D.; Markham, P.G.; Brown, J.K. A phylogeographical analysis of the Bemisia tabaci species complex based on mitochondrial DNA markers. Mol. Ecol. 1999, 8, 1683-1691. [CrossRef] [PubMed]

36. De Barro, P.J.; Driver, F.; Trueman, J.H.; Curran, J. Phylogenetic relationships of world populations of Bemisia tabaci (Gennadius) using ribosomal ITS1. Mol. Phys. Evol. 2000, 16, 29-36. [CrossRef] [PubMed]

37. Orodho, A.B. Country Pasture/Forage Resource Profiles, Kenya; National Agricultural Research Station: Kitale, Kenya, 2006.

38. Mware, B.; Olubayo, F.; Narla, R.; Songa, J.; Amata, R.; Kyamanywa, S.; Ateka, E. First Record of Spiraling Whitefly in Coastal Kenya: Emergence, Host Range, Distribution and Association with Cassava Brown Streak Virus Disease. Int. J. Agric. Biol. 2012, 470, 411-415.

39. Mehta, P.; Wyman, J.A.; Nakhla, M.K.; Maxwell, D.P. Transmission of tomato yellow leaf curl geminivirus by Bemisia tabaci (Homoptera: Aleyrodidae). J. Econ. Entomol. 1994, 87, 1291-1297. [CrossRef]

40. Muturi, C.N.; Ouma, J.O.; Malele, I.I.; Ngure, R.M.; Rutto, J.J.; Mithofer, M.; Enyaru, J.; Masiga, D.K. Tracking the Feeding Patterns of Tsetse Flies (Glossina Genus) by Analysis of Blood meals Using Mitochondrial cytochromes Genes. PLoS ONE 2011, 6, e17284. [CrossRef] [PubMed]

41. Thompson, J.D.; Higgins, D.G.; Gibson, T.J. CLUSTAL W: Improving the sensitivity of progressive multiple sequence alignment through sequence weighing, positions-specific gap penalties and weight matrix choice. Nucleic Acids Res. 1994, 22, 4673-4680. [CrossRef] [PubMed] 
42. Ronquist, F.; Teslenko, M.; Van Der Mark, P.; Ayres, D.L.; Darling, A.; Hohna, S. MrBayes 3.2: Efficient Bayesian Phylogenetic Inference and Model Choice Across a large model space. Syst. Biol. 2012, 61, 539-542. [CrossRef] [PubMed]

43. Peter, J.G. Reversible jump Markov chain Monte Carlo computation and Bayesian model determination. Biometrika 1995, 82, 711-732.

44. Ayres, D.L.; Darling, A.; Zwickl, D.J.; Beerli, P.; Holder, M.T.; Lewis, P.O.; Huelsenbeck, J.P.; Ronquist, F.; Swofford, D.L.; Cummings, M.P.; et al. BEAGLE: An application programming interface and high-performance computing library for statistical phylogenetics. Syst. Biol. 2012, 61, 170-173. [CrossRef] [PubMed]

45. Boykin, L.M. Bemisia tabaci Nomenclature: Lessons learned. Pest Manag. Sci. 2014, 70, 1454-1459. [CrossRef] [PubMed]

46. Maruthi, M.N.; Hillocks, R.J.; Mtunda, K.; Raya, M.D.; Muhanna, M.; Kiozia, H.; Rekha, A.R.; Colvin, J.; Thresh, J.M. Transmission of Cassava brown streak virus by Bemisia tabaci (Gennadius). J. Phytopathol. 2005, 153, 307-312. [CrossRef]

47. Esterhuizen, L.L.; Mabasa, K.G.; van Heerden, S.W.; Czosnek, H.; Brown, J.K.; van Heerden, H. Genetic identification of members of the Bemisia tabaci cryptic species complex from South Africa reveals native and introduced haplotypes. J. Appl. Entomol. 2012, 136, 1-14.

48. Legg, J.P.; Jeremiah, S.C.; Obiero, H.M.; Maruthi, M.N.; Ndyetabula, I.; Okao-Okuja, G.; Bouwmeester, H.; Bigirimana, S.; Tata-Hangy, W.; Gashaka, G.; et al. Comparing the regional epidemiology of the Cassava Mosaic and Cassava Brown Streak pandemics in Africa. Virus Res. 2011, 159, 161-170. [CrossRef] [PubMed]

49. Brown, J.K. The Bemisia tabaci complex: Genetic and phenotypic variation and relevance to TYLCV-vector interactions. In Tomato Yellow Leaf Curl Virus Disease: Management, Molecular Biology, Breeding for Resistance; Czosnek, H., Ed.; Springer: Dordrecht, The Netherlands, 2007.

50. Thompson, W.M.O. A new host plant species for the cassava biotype of Bemisia tabaci (Gennadius) (Hom., Aleyrodidae). J. Appl. Entomol. 2003, 127, 374-376. [CrossRef]

51. Legg, J.P. Epidemiology of a whitefly-transmitted cassava mosaic geminivirus pandemic in Africa. In Bemisia: Bionomics and Management of a Global Pest; Stansly, P.A., Naranjo, S.E., Eds.; Springer: Houten, The Netherlands, 2010.

52. De Barro, P.J. The Bemisia species complex: Questions to guide future research. J. Integr. Agric. 2012, 11, 187-196. [CrossRef]

53. Otim-Nape, G.W.; Bua, A.; Thresh, J.M.; Baguma, Y.; Ogwal, S.; Semakula, G.N.; Acola, G.; Byabakama, B.; Martin, A. Cassava Mosaic Virus Disease in Uganda: The Current Pandemic and Approaches to Control; Natural Resources Institute: Chatham, UK, 1997.

54. Jarvis, A.; Ramirez-Villegas, J.; Campo, B.V.H.; Navarro-Racines, C. Is cassava the answer to African climate change adaptation? Trop. Plant Biol. 2012, 5, 9-29. [CrossRef] 